\title{
Intertwining lives and logics: Household and informal economies in Cape Town
}

\author{
Sophie Oldfield
}

Sophie Oldfield, University of Cape Town, Department of Environmental and Geographical Science, South Africa (sophie.oldfield@uct.ac.za)

\begin{abstract}
Enabling households to make ends meet, the practices of small, informal businesses are not simple, but bound up in the struggles of households and the social and economic relationships that weave local economies together. This paper draws on stories of local businesses in an impoverished Cape Town township to situate these diverse logics and strategies, the histories and aspirations that shape small business success and struggle. Drawing on interviews and mapping every informal sector business in the neighbourhood, I reflect on the specific difficulties of running a business in the context of poverty, including unreliable and inadequate incomes, difficulties of credit, as well as the challenges of operating business on a small scale. This material demonstrates the community-based, as well as livelihood, logics that motivate local business owners as well as sustain their livelihoods. The paper concludes with an argument that the neighbourhood economy, instead of a vehicle driven primarily to maximize profit, forms an intimate part of peoples' lives. This more multifaceted and embedded analysis stretches overly narrow notions of the informal economy, its limits and logics.
\end{abstract}

Keywords: Informal economy, popular economy, livelihoods, survivalist, community, competition

\section{Introduction}

"We can't stay any longer' Fearing for their lives, Somali businessmen have fled Valhalla Park, where roaming mobs have firebombed and looted their shops" (Cape Argus, 11 July 2012: 1)

One of many xenophobic attacks in recent city history, in mid-July 2012 four Somali-run shops were burnt to the ground in Valhalla Park, an impoverished neighbourhood on the Cape Flats of Cape Town. The shops were looted after 'locals' threw petrol 'bombs,' burning out their premises. Following this violent episode, Somali-run shops were shut down, their owners and employees fleeing the neighbourhood. There are mixed feelings about this event and diverging interpretations of what led to this violent outburst. One resident describes the burnt-out remnants of stores, the empty spaces where they were, as initially 'surreal.' She suggests the first attack was related to a local gang fight, the shopkeeper a target because his connection to the neighbourhood was forged through a rival drug-dealer (personal communication, 19 July 2012). A community leader stresses that some local business owners have stoked the existing discontent with 'foreigners', exploiting both the longer-term rumours about foreigners and their business dominance, as well as the increasing tension between gangs in the neighbourhood (personal communication, 22 July 2012).

Not geared primarily toward maximizing profit, neighborhood businesses face significant threats from foreign-owned and formal businesses running off more entrepreneurial business models (see Charman et al., 2012; Gastrow \& Amit, 2013). The challenging realities that shape and sustain small businesses in this neighbourhood and across poorer parts of Cape Town (and every other South African city) lie below the surface of this violence (Charman \& Piper, 2012). Enabling households to make ends meet over the short and long-term, the practices of small (informal) businesses are not simple, but bound up in the struggles of households and the social and economic relationships that weave the neighbourhood together. 
This paper draws on stories of local businesses in this neighbourhood to situate these diverse logics and strategies, as well as the histories and aspirations that shape small business success and struggle in this context. Though not focused on a comparative analysis of foreign-owned business practices and models, nor a direct attempt to explain past or present xenophobic violence, these narratives help elaborate the logics of local livelihoods, and their intimate and durable connections to household and community context.

The narratives demonstrate the ways in which small businesses constitute the neighborhood economy - the 'informal sector,' highlighting their intimate embedding in the social and economic logics that shape households as well as community relationships and networks. These dynamics are what many in this neighbourhood understand as 'under threat from' newer businesses run by 'foreigners.' The paper draws from research completed as part of a community-based partnership with the Valhalla Park United Front Civic, a process that included interviewing and mapping every informal sector business in the neighbourhood from January to March 2012. The first section of the paper considers the specific difficulties of running a business in the context of poverty, including unreliable and inadequate incomes, difficulties of credit as well as the challenges of operating business on a small scale. The second section reflects on the community-based, as well as livelihood logics that motivate local business owners as well as sustain their livelihoods. The paper concludes with an argument that the neighbourhood economy, instead of a vehicle driven primarily to maximize profit, forms an intimate part of peoples' lives. This more multifaceted and embedded analysis stretches often narrow notions of the informal economy, its limits and logics.

\section{Informal economies, household livelihoods and poverty}

There is broad policy acknowledgement that informality is a significant part of the South African economy (Rogerson, 2013). The informal sector moreover particularly sustains family and community economies in townships across South African and southern cities. Many analyses, however, frame issues of the informal economy as local, with limited connections to the formal economy, and thus as organised around subsistence, practices that are understood as broadly uncompetitive. In the South African context, for instance, Davies and Thurlow (2009) estimate up to two thirds of the South African population are involved in the informal economy, be it through informal employment, employed by an informal business or a self-owned enterprise. Despite issues around availability and reliability of data (Devey et al., 2006), researchers can confidently argue that the informal sector has exploded - drawing in or providing livelihoods for from 965,000 (1997) to 2.3 million people in 2005 (Devey et al., 2006) and absorbing between 10-18\% of the labour force (Valodia, 2006). A range of figures estimate the contribution of the informal economy to GDP, ranging from a conservative $7-11 \%$ to approximations at a Cape Town city-scale that suggest the informal economy contributes 18-20\% of GDP (City of Cape Town, 2003 in Battersby, 2012). Recognized by Hart (1973) nearly forty years ago, informal economies remain critical areas of southern urban economies. Yet, nonetheless, complex practices of economic informality are frequently the least acknowledged, a silence that marginalizes this type of work and the people making a living in this type of economic activity.

Valodia (2006) stresses the need for empirical research that moves beyond macroanalyses, in the grounded, everyday lived experiences that people engaged in informal economies navigate and experience. This sort of material helps fuel an extensive debate that questions how we define what is informal (Chen et al., 2004), challenging simplistic notions that it encapsulates simply 'local' businesses and activities that are illegal or on the margins of our cities, essentially unimportant for the broader national economy. This rich literature emphasizes instead the heterogeneity and complex relationalities that connect formal and informal across South African cities. Here I draw from this foundation and the set of 
assumptions it brings to thinking about city economies.

More particularly, I build from a debate that considers neighbourhood economic practices as 'popular economies' (Hull \& James 2012), drawing our attention away from the binaries of informal-formal, state-regulated-unregulated, or illegality-legality, that too simplistically divide the debate into technocratic or instrumentalist notions of the economy. They suggest instead that, in contrast, the term 'popular economies' stresses "the embeddedness of economic practices and institutions in broader cultural milieux; their reliance on ideas about luck, fortune, fate and the like; and the way they speak to dreams of wealth, equality, and the future.” (Hull \& James, 2012: 9)

In making this analytical shift, I explore as Neves and du Toit (2012: 131) propose: "the imperatives and networks that underpin practices of generating, accumulating and managing wealth at the margins of the economy". Through a detailed qualitative empirical study, the paper contributes to their broader problematic that: "The [informal] sector tends to be viewed in homogeneous and undifferentiated terms, misrecognized and misunderstood because of normative notions of economic 'rationality', or found wanting when measured with the yardstick of 'entrepreneurism' predicated on rational, self-interested, utility - maximising individuals. Informal sector workers are prone to not keeping written business records, eliding enterprise and domestic accounts, and extracting seemingly unsustainably high levels of resources from their enterprises. They are motivated not by business plans but by various social and redistributional logics." (2012: 131-132) It is these latter social and redistributional logics, and their relationship to household realities and community mores and needs, that shape the discussion in this paper.

This research highlights two relational logics: first, small informal businesses reflected household (business owners and customers) constraints, the precarious temporal and purchasing contexts that shape everyday economies and family life. Across a background of economic marginalization, both customer and owner often struggled to get by, a context fundamentally shaping the operations of neighbourhood businesses. At the same time, and the second part of the argument here, the logic of business was shaped in the interplay between community-neighbourhood relationships and the role of informal businesses. Over and over again, business owners referred to the community and their respective role in it as an important concern that shaped business. The informal economy in this context then is not only shaped by the necessity to source an income to survive and the desire to improve family and household circumstances. In all their varied ambitions, and stories of perseverance, many local businesses are triggered, driven, and sustained as well, by a desire to give back to the community. Selflessness and small-scale philanthropy play a critical role in the creation, sustenance, and sustainability of many small businesses in neighbourhood context. The stories, explored below, help ground the logics that sustain and build the informal economy, as well as the tensions that they generate - be-it in competition with foreign-owned enterprise, the point of the departure the paper begins with, or the vagaries of informal economies at neighborhood scale. The remainder of the paper draws on narratives that explore the nature of business, the varied linkages and logics built in relationships and aspirations for community, turning lastly to household dynamics and their often-constrained interplay.

\section{From Tuck Shops to Pool Houses: Everyday business}

More than anything, businesses are an intimate part of peoples' lives, extensions of owners' values, as well as connections to community and identity. From Rabia's Mobile, to Yusaf's Tuck shop, to Boy's Fruit and Veg, the area is inundated with shops that seemed, on first glance, to have been created simply as a method for economic survival. In almost every instance, however, this preconception was proved wrong. Kadeer's Tuck Shop, for example, appeared initially to be a typical small informal business. No signage, very little 
advertisement, though boasting 1-2 conspicuous back rooms swollen and distended with knick-knacks and daily necessities. Kadeer opened his shop 8 years ago, when he "needed to make more money but wanted to give back to the community at the same time" (personal communication, 2/16/12). The shop sells little necessities, such as cigarettes, sweets, and batteries, and he purchases these from nearby wholesalers, similar to many of the tuck shops in the area. He explained that the shop stays open for only six months each year, since he uses the other six months to travel. A worldly man, it was unclear how he found the money to travel so extensively, since he insisted that his tuck shop provided only for food and necessities, often on credit, for his community (2/09/12).

Uncle Gesant, a short gentleman probably in his sixties with a kindly presence and warm smile, is the owner of Dulsie's Spices- selling spices, vegetables and blank CDs and DVDs. Gesant said that many years ago he used to have a big shop with shelves all around his lounge but now he ran his small business just to keep himself busy and support him and his wife. When asked whether he wanted to expand his shop, he replied with a look of anguish on his face: "You expand your shop, then the people ... yoh! No man!" He was content to keep his business running on a small scale; the thought of running a "whole shop" seemed to stress him out.

Mr. Paulse explained that he ran his shop "instead of sitting. Because when you sit, you get older quicker ... It's just to keep me busy you know.” When we met him, he had been running his shop for about two years; he opened it shortly after retiring. He explained that his business doesn't make much money on most of the products he sells, because he tries to keep his prices low; in other words, he is largely just making back what he spends. He said that cool drinks were the only products that he made a decent profit on and they were good products to stock because of their long shelf lives. According to Mr. Paulse, cigarettes were a "big draw card" in the home shop business. But despite the potential benefits of selling cigarettes, he chose to not sell them for religious reasons and because he knows they are bad for people. He loses customers who smoke because people are likely to shop elsewhere where they can buy everything they want from the same shop. But that did not seem to bother him, as long as he was not losing money and the shop was keeping him busy. In sum, Mr. Paulse was satisfied with his tuck shop.

The figurative godmother of the Community Pool Club, for instance, Kathleen precariously balanced her grandson on her left knee, reaching simultaneously for another grandchild, chastising them both for torturing the family's new puppy. From the moment we met, it was clear: this woman could multitask. And this is perhaps because Kathleen has been filling her home, her thoughts, and her heart with the neighbourhood youth for almost ten years now. Her survival depends on her ability to juggle constantly the needs of her community with her own and those of her household. Kathleen worked at a hospital in the center of Cape Town until 2009, after which she retired with a pension. She now lives in her home, adjacent to the pool club, with her two daughters and six of her grandchildren. The scene at her house is rich, full of activity, laughter and curiosity in our interview. The pool club is spacious and bright, the walls plastered with framed photographs of members and their respective successes. The outside boasts a garden, tended by the neighborhood's Rasta community. The gaming machines seem to tower over young players, who eagerly grasp the joysticks with miniature hands. This space serves as a sanctuary for neighbourhood youth, a haven that keeps many off the streets and out of the troubles that afflict many in the community today. Children pay 50c to play a game and R1 to partake in a round of pool, a small fee for the camaraderie and stability that draw youth to the establishment everyday from 2:30-8:00pm.

The stories of these businesses suggest that the informal economy exists in peoples' lives not only as a source of employment or livelihood alone. Businesses form part of peoples' 
everyday lives, linking them into the neighbourhood.

\section{Neighbourhood niches: Individual and communal motivations}

The motivation to give back to the community proved a powerful trigger for the creation of many businesses. A number of business owners explained that their main reasons for operating within the informal economy were to assist and improve their own community. Achmat Josephs, for example, runs his madrasah, teaching Arabic full time for a small fee per student. Although not initially obviously a business, this service sustains him and acts as a means to educate the youth and ensure they grow into community members who can be responsible and accountable in their environment. Similarly, Mrs Arendse began her home business as a way to keep children in the community fed on the weekends when they are not receiving free meals at school. Today, the revenue is measly, and most of it goes to her feeding scheme business. She is clearly not running the business for herself. The idea to create a business in order to give back to the community comes from varied and unconventional sources. Kadeer explained, "The biggest reason I run this business is to give back to the community. When I sell things for cheaper than anywhere else, it helps to keep money within the community rather than flowing out of it. This idea came to me from God" (2/09/12). Proudly, Kathleen explained her deepest passion: "What I care most about is youth development and working with children. I love running the pool club because I feel as if I'm giving back to the community while providing a way for my family to live.” She chuckled when asked about the profitability of the pool club. "Money is not the main reason for this place. We hardly make any, but we started it so that the kids would have a place to go" (2/16/12). Gail Peterson, principal and pioneer of Valhalla Park Educare Centre, re-told a remarkable story of how her crèche came to be where it is now. She emphasizes:

"I think this is a special thing that happened in my life. I was a factory worker; I had no education. I saw the factories closing. What did I do? I went to high school, I did standard eight over two years, I did some other trainings ..."

After the various training courses Gail started the crèche in her back yard with eight children twenty years ago. Shortly after opening, some social workers recognized the good work she was doing and organized for her to use the hall at which they were still operating when interviewed.

Since then she said she has been going "from strength to strength." Now she has a trained staff of twelve that cares for 130 children at the Centre. She explained the challenges she may face from operating in a context where many adults are unemployed. She said that she "must" care for certain children for free because their families can't afford the fees. These include children looked after by their grandparents who do not work and children who have no one to look after them at home. If a child's parents are unemployed, she cares for the child for free so that the parents can go and look for work during the day and she is passionate about the services that she is able to provide to the community.

Aziza at Gammie's Fish, a home shop best known for providing fish at affordable prices, spoke explicitly about how important the community is to the way they (her and her husband) run the business. She said:

"Our business is here to serve the poor, it's the poor serving the poor.... Here in Valhalla Park we look after each other. If someone comes with R2 or R3, I'll see to them. I'll help you because you need it. In business we must see to each other's needs."

Aziza's conception of business didn't exist outside of “community.” Their fish business forms a much bigger part of her and her husband's lives than a form of income, it is their connection to the community and at the same time it defines their place in the community. At 
the time when interviewed, she said that they were struggling to source fish cheaply because the fishing boats from which they normally bought had made very small catches and the fish were very expensive. The values embodied in the Gammie's Fish business are displayed in her reflection on how she feels when there's no fish available. She explains: "It is a terrible thing for the people because they are poor. They buy fish heads to make food, if there is no fish, there is no fish heads."

The distinctive expressions and meanings of business in this neighbourhood reflect owners and their business models built in and from a deeply local and personal economy. This is not a one-way street or relationship, however; linkages to the community also are what sustain businesses, the relationships through which they continue to exist.

\section{Community as a Sustainer: Helping Businesses to Thrive and Prosper}

While a desire to support and give back to the community was evidently a main reason for business creation, the reciprocity between community and business also sustains many small household businesses. Many of the interviewees explained ardently that their businesses would have never succeeded without the charitable help of neighbors, religious institutions, or community organizations. As Ross suggests, economic position is not just defined by how much money one has. "Other [indicators] include one's social networks and the ways that one may be able to activate these to access resources, including money, food, care, and access to institutions (May, 2000); one's capabilities' and capacities to mobilize these; and one's inclusion or exclusion from these systems" (2010: 107). Social networks and their meaningfulness manifest further in this neighbourhood informal economy, serving as the backbone that enables businesses in the area to thrive and prosper.

Philanthropic actions between community members are often what keep businesses afloat in hard times. Many business owners spoke of instances when they looked towards governing social bodies such as mosques, churches, or the Civic, for aid when business began to default or they feared they would be forced to shut down. Salyeyah, who owns her own home sewing business, explained, "I could not have began or continued this business without the help of the Muslim community. The mosque gave me sewing machines when I lost my job. Today, they help me with groceries when times at the business are hard" (2/09/12). Similarly, when one of the soup kitchen operations are threatened, friends and neighbors sometimes help by donating vegetables whilst the butcher often provides free bones to flavor the broth. At the Pool Club, all of the games and pool tables were donated from individuals and organizations within the community. Altruism and care acts as sustenance not just in terms of physical donations, but in the form of counsel and guidance as well. For instance, when interviewing Samaya about her tuck shop, we learnt that she is currently at risk of being evicted; an event that would be disastrous for her family and business. The Civic member interviewing with us almost bellowed in response, “They can't close your shop down.” In her posture, in the agency of her hands, in the eloquence and sharpness of her voice, "the Lion," as our partner was known, willingly offered her time and these services for free, although she had not previously known Samaya well at all (personal communication, 2/23/12). Our interview and visit proved an opportunity for consultation and advice to avoid the eviction.

Most business owners explained that the lack of economic stability within the informal economy makes running their operation difficult. "Two weeks are up, two weeks are down" (Ferusse, 2/23/12); "Everyday is fish day, but not everyday is catch day" (Salyeyah, 2/09/12). Informal economic activities must cope with fluctuating businesses. Often, from the first to the fifteenth of the month, business booms, then becomes totally stagnant until the very end of the month when individuals receive a monthly paycheck (Reynolds, Mila, 2/16/2012). But this is only a rough approximation of the cycle. With no way to ensure sustenance or revenue day to day, business owners' ability to rely on outside actors within the community to help 
sustain their operations is crucial. This custom ensures the livelihood of the informal economy in Valhalla Park. It's a fundamental characteristic of the order of operations within this tight knit community; as a Civic member expressed passionately, "An injury to one is an injury to all” (2/23/12).

Due to the lack of stability so intrinsic to business within the informal economy, the shelf life of many economic operations can be short lived and temporary, despite the attention and drudgery which goes into getting them off the ground and running. Oftentimes, however, the need for a business or service in a community battles the inherent temporality it would otherwise face as a part of the informal economy. When asked about the future of their small business, many individuals acknowledged a need for the service within the community as the main driver of its sustainability. If it is of altruistic nature, often the future of a business does not depend on its weekly revenue or the challenging price fluctuations of the formal market, but instead on an intrinsic need in the community for the provided service. This reality allows many small business owners in Valhalla Park to be confident that the time, exertion, and effort they enact to keep their business afloat today, will continue to pay off in coming years, on the medium term.

When asked what she saw for the future of her business, Kathleen responded, for instance: 'As long as there are children in this community, there will be a place for our business and for the Pool Club. Its survival is not based on me and the money I need but on what it gives back to the community and how it fixes a big problem in [the neighbhourhood]" (Kathleen, 2/16/12). Mr. Daniels felt similarly when confronted with the potential temporality of his business. He explained:

"I run my business so that the youth can have an opportunity to see what an honest living looks like. There are not enough jobs for the young in our community, and by running my business, I am doing what little I can to fix that problem. The business will stay running because I will do this service for my son, and he in turn will do it for his son. It is this need in the community that will make sure our barber business does not close down." (2/16/12)

Through a multi-faceted understanding of the connection between business operations and the networks and relationships they sustain in the neighborhood, we are better able to grasp how the informal economy works to serve and simultaneously profit from the community in substantial, non-economic ways.

\section{Household economies and scales of business}

A tuck shop owner, Mr Paulse is a warm, retired man. Soft spoken and relaxed, he welcomed us into his home on two occasions to sit and chat about his business. His lounge decorated with family photos, two fish tanks and one or two pieces of art with bible verses reflecting his commitment to the Christian faith, we sat and discussed many of the challenges he faces running his shop. The first thing noticeable about his shop before he told us anything about it was the scale of it; the shop room couldn't be bigger than three-by-four meters. On the one side of the room was a window behind security bars through which he could interact with his customers; opposite this window he placed a fridge, with access to a wall of shelves. Mr Paulse's product base was small; at the time he was selling chips, sweets, cool drinks, bread, bompies [ice sticks] and a few other food products. This small scale of operation seemed, in itself, to be the root of most of the challenges that he, himself identified. Another issue surfaced in not knowing which products people wanted. He explained:

"Its very difficult because you don't know what people want, what the children want. Everyone differs ... so I'm trying to get a bit of each. So I buy one of these (multi-packs of chips), one of these, one of these, then I see which one sells fast, then maybe next time I buy two of that one and none if its selling slow." 
This issue was exacerbated by the perishable nature of food products. He explained that he was reluctant to buy products that wouldn't sell well because if he didn't sell them fast enough they would expire. Bread was considered a particularly difficult product in this regard because of its short shelf life if he doesn't sell it in one or two days he generates a loss. Although big multi-packs of chips only cost R20 to R30 [US\$2 to 3] and bread loaves about R7.50 [ 75 US cents], these mark potentially big losses if these products do not sell.

Another challenging aspect related to the economic context in which businesses operate was the reality that people buy very small amounts of foodstuffs, often buying for only one meal at a time. He elaborated: "People around here, they are poor people you know, people can't buy a whole packet of sugar, they buy R1 [ 10 US cents] of sugar.” He then explained that, to meet the demands of the market, he buys a big packet of sugar, coffee or mealie meal and he divides those big packets into smaller packets that he then sells individually for R1 each. This practice enables him to make back the money he spends on the big packets and a little bit of profit. But, because people buy such small quantities, it takes a while to sell a whole packet and see any of the profit.

Yvonne and her husband, located less than five minutes walk from Mr. Paulse's tuck shop, own and run "NIKS VINIET" (Nothing for free), a home shop on the corner of a road located directly opposite a church. Yvonne highlighted many of the same challenges that $\mathrm{Mr}$. Paulse spoke about, of particular interest here, is the nature of consumer behaviour in this area. She said: "People buy little, very little.” Minutes before she told us this we had seen an elderly lady come into the shop and go away with a single small tin of tomato paste. She said that this practice of buying such small quantities is the norm and was a significant challenge to the well being of her shop. In addition to buying such small volumes, Yvonne complained that the inconsistency in purchasing patterns made it tricky to run a small shop. NIKS VINIET used to stock bread but she faced the same difficulty as Mr. Paulse, often left with bread close to reaching its expiry date. When this happened she said she would have to give the bread away, thereby making a loss. She has chosen to discontinue stocking bread because it was too difficult to sell to people with such inconsistent, unreliable purchasing habits. Many people, Yvonne's husband included, are only able to access work opportunities on a casual basis. When people's livelihoods depend so heavily on forms of income that is both inadequate and unreliable, their eating habits tend to reflect the inconsistency of their income.

Adorning the walls of the covered outside area that leads to Yvonne's shop window are a number of signs or notices, the signs are cut out of bright luminous cardboard- green, pink, orange and yellow, with text written in blue or lack permanent marker pen. One sign read "Halal liver spread," another "DVDs and CDs." But the sign that jumped out most read: "NO CREDIT. Bad paid got KILLED.” The violence of the language on the bright yellow sign and our welcome from Yvonne clashed. She explained that she had lost a lot of money from selling things on credit to people and never being paid back. "You get a lot of stories from people:" they will pay at the end of the month or when they received their [state welfare] grants but she was often left carrying the cost of those products herself. As a result of these losses, Yvonne now has a strict policy on credit: no credit. Customers who had not settled their credit accounts had "killed" the opportunity for anyone to buy goods on credit.

For a business operating on a modest scale any default on credit payment could be the difference between breaking even and failing in tough months, central difficulties in a context where both customer and business owner are poor. Moreover, competition in this stretched and impoverished context presents a challenge. All of the shop owners interviewed, at some point, expressed the difficulty they faced from competition from shops in the area owned by people who were foreign. Because local business strategies are often informed by principles other than profit- maximizing market logic, different, more 'entrepreneurial' business models 
tend to make the former appear inefficient and flawed. Anti-foreigner sentiment slipped easily and worryingly into the climate surrounding the xenophobic attacks of 2008 that swept the country (Gumede, 2008). Mr Paulse emphasized, for instance: "The Nigerians and the Somalians- they took over. They can sell cheaper... I believe they have one owner. I see one bakkie going around distributing goods and sets up many shops... they buy in bulk." Graham, another home shop owner, lives five houses down from his brother who also runs a shop selling meat during the weekends. He explained how difficult foreign competition made running his business, but was reluctant to explore collective strategies with his brother or other 'local' shop owners. Gesant echoed this reluctance to upscale to a more market-oriented business model even in the face of competition.

Responses of local, neighbourhood shop owners at one level are contradictory. On one hand, there is a marked hostility toward foreign competition; on the other hand a reluctance to change business models to be more competitive and proactively stake a claim in the home shop neighbourhood industry. These patterns resonate with research completed by the Sustainable Livelihoods Foundation (Charman et al., 2012) and the African Centre for Migration and Society (Gastrow \& Amit, 2013) on the phenomenon of foreign shops and their impact on neighbourhood economies. In Somalinomics, Gastrow and Amit discuss the mix of 'competitive and cooperative' practices that Somali traders draw on, sharing transport and information on wholesalers prices, while buying stock individually, and sometimes jointly investing in setting up shops (2013: 23-25). Charman et al. (2012), similarly, highlight the approach to running spaza shops based on entrepreneurial business models introduced by 'foreign' owners to Delft, another Cape Town township. They argue persuasively that in light of these practices, 'local' small shops characterized by a 'survivalist' approach often have been forced out of business. Present practices stand in stark contrast to the way the spaza shop market operated when price competition was considered unethical and unfair (Charman et al., 2012). Certainly in the context where this research was completed, foreign competition and a more market-based approach to running neighbourhood businesses stands in contrast to the intimate embeddedness of small businesses in people's lives, the logic that this paper explores and that binds together the informal or popular economy in this context.

\section{Conclusion}

In contexts of informality and subsistence, neighbourhood economies weave together an entanglement of people, their desires, values, relationships, histories, and experiences. These expressions are bound up in everyday lives and practices. Small business owners are reluctant to change business models because their lives and identities are informed by and invested in their businesses. Changing that would mean altering the ways in which they relate to the community, and imagine themselves within it. Instead of a focus on maximizing profit and running businesses based on market logic, businesses are extensions of owners, embodying values, aspirations and relationships. These practices ground owners' identities in neighbourhood and household relations, a means and a site through which connections to the community are defined and maintained. These are the threads that weave together local logics and livelihoods; a socio-economic fabric that sits in often-precarious relation with 'foreign' and 'formal' market practices that many perceive as a threat.

\section{Acknowledgements}

Thank you to the many business owners who agreed to be interviewed and to share their experiences. This research was designed and completed in partnership with the United Front Civic Organisation. Thank you to the Civic participants, especially Mrs. Gerty Square, their coordinator. Thank you too to students from University of Cape Town and Stanford University who participated in the research project and to Stanford University's Bing Cape 
Town Centre for providing the funding for the student participation in the project, as well as the South African National Research Foundation, for funding the research as part of a Community Engagement Grant (No. 774408).

\section{References}

Amin, A \& Thrift, N. (2007) Cultural-economy and cities. Progress in Human Geography, 31(2), pp. 143-161.

Ballard, R., Habib, A., Valodia, I. \& Zuern, E. (2005) Globalization, marginalization and contemporary social movements in South Africa. African Affairs,104 (417), pp. 615-634.

Battersby, J. (2011) Urban food insecurity in Cape Town, South Africa: An alternative approach to food access. Development Southern Africa, 28(4), pp. 545-561.

Charman, A., Petersen, L. \& Piper, L. (2012) From local survivalism to foreign entrepreneurship: the transformation of the spaza sector in Delft, Cape Town. Transformation 78, pp. 47-53.

Charman, A. \& Piper, L. (2012) Xenophobia, Criminality and Violent Entrepreneurship: Violence against Somali Shopkeepers in Delft South, Cape Town, South Africa. South African Review of Sociology 43(3), pp. 81-105.

Chen, M.A., Vanek, J. \& Carr, M. (2004) Mainstreaming informal employment and gender in poverty reduction: A handbook for policy-makers and other stakeholders, Ottawa: International Development Research Centre.

Davie, K. \& McDermott, S. (2011) South Africa’s hidden economy. Mail \&Guardian Online, http://mg.co.za/article/2011-08-19-the-hidden-economy (accessed 19 August 2011).

Davies, R. \& Thurlow, J. (2010) Formal and Informal Economy Linkages and Employment in South Africa. South African Journal of Economics 78(4), pp. 437-459.

Devey, R., Skinner, C. \& Valodia I. (2006) Definitions, data and the informal economy in South Africa: a critical analysis, in Padayachee, V (ed.), The development decade: Economic and social change in South Africa 1994-2004, Human Sciences Research Council Press: Pretoria, pp. 302-326.

Gastrow, V. \& Amit, R. (2013) Somalinomics: A Case Study on the Economics of Somali Informal Trade in the Western Cape. Johannesburg: African Centre for Migration and Society, University of Witwatersrand, pp. 1-37.

Gray, M. (2006) The progress of social development in South Africa. International Journal of Social Welfare, 15(1), pp. 53-64.

Gumede, W. (2008) Failing its people: The government of South Africa is neglecting its own poorest communities, with deadly results for immigrants from other African nations. Guardian UK www.guardian.co.uk/commentisfree/2008/may/20/failingitspeople (accessed 20 May 2008).

Hart, K. (1973) Informal Income Opportunities and Urban Employment in Ghana. Journal of Modern African Studies, 11(1), pp. 61-89.

Hull, E. \& James. D. (2012) Introduction: Popular economies in South Africa. Africa, 82(1), pp. 1-19.

Neves, D. \& Du Toit, A. (2012) Money and Sociality in South Africa’s Informal Economy. Africa 82(1), pp. 131-149.

Robins, S, Cornwall, A, \& Von Lieres, B. (2008) Rethinking citizenship in the postcolony. Third World Quarterly, 29(6), pp. 1069-1086.

Rogerson, C.M. (2013) Improving market access opportunities for urban small, medium and micro-enterprises in South Africa. Urbani izziv 24(2), pp. 133-143.

Ross, F. (2010) Raw Life, New Hope: Decency, Housing and Everyday Life in a PostApartheid Community. Cape Town: University of Cape Town Press.

Sharp, L. (2011) Trickery in employment figures. Mail \& Guardian Online. 
http://mg.co.za/article/2011-01-28-trickery-in-employment-figures (accessed 28 January 2011).

Valodia, I., Lebani, L., Skinner, C. \& Devey. R. (2006) Low-waged and informal employment in South Africa. Transformation 60, pp. 90-126. 